\title{
ADDITIONAL AMERICAN WOODCOCK NOTES FOR MANITOBA
}

ROBERT W. NERO, Manitoba Wildlife Branch, Box 14, 1495 St. James Street, Winnipeg, Manitoba. R3H OW9

In 1977 a fairly comprehensive report of the status of the American Woodcock in Manitoba was published (Nero, Blue Jay 35:240-56, 1977). The present note provides data on the first known nests for the province, other breeding records, and some additional sightings.

Previous breeding information included a record of an egg laid on top of snow (Piney, 20 April 1970), a brood of young 2 to 3 days old (Reaburn, 24 May 1975), a newly hatched chick (East Braintree, June 1976), and a brood several days old (Birds Hill, 12 May 1977).
It was inevitable that sooner or late someone would find an Americar Woodcock nest in Manitoba, but it is curious coincidence that the first tw nests should be found on the sam residential property by the same famil in two separate years. A woodcock nes with a full clutch of four eggs was foun on 14 May 1979, by George Monkma near his home 5 miles south and 1 mil east of Richer, about 25 miles south east of Winnipeg. The nest was studie by George's son Gary through in cubation and hatching. My son Broo and Dennis Fast observed and photc graphed the incubating bird on $21 \mathrm{Ma}$

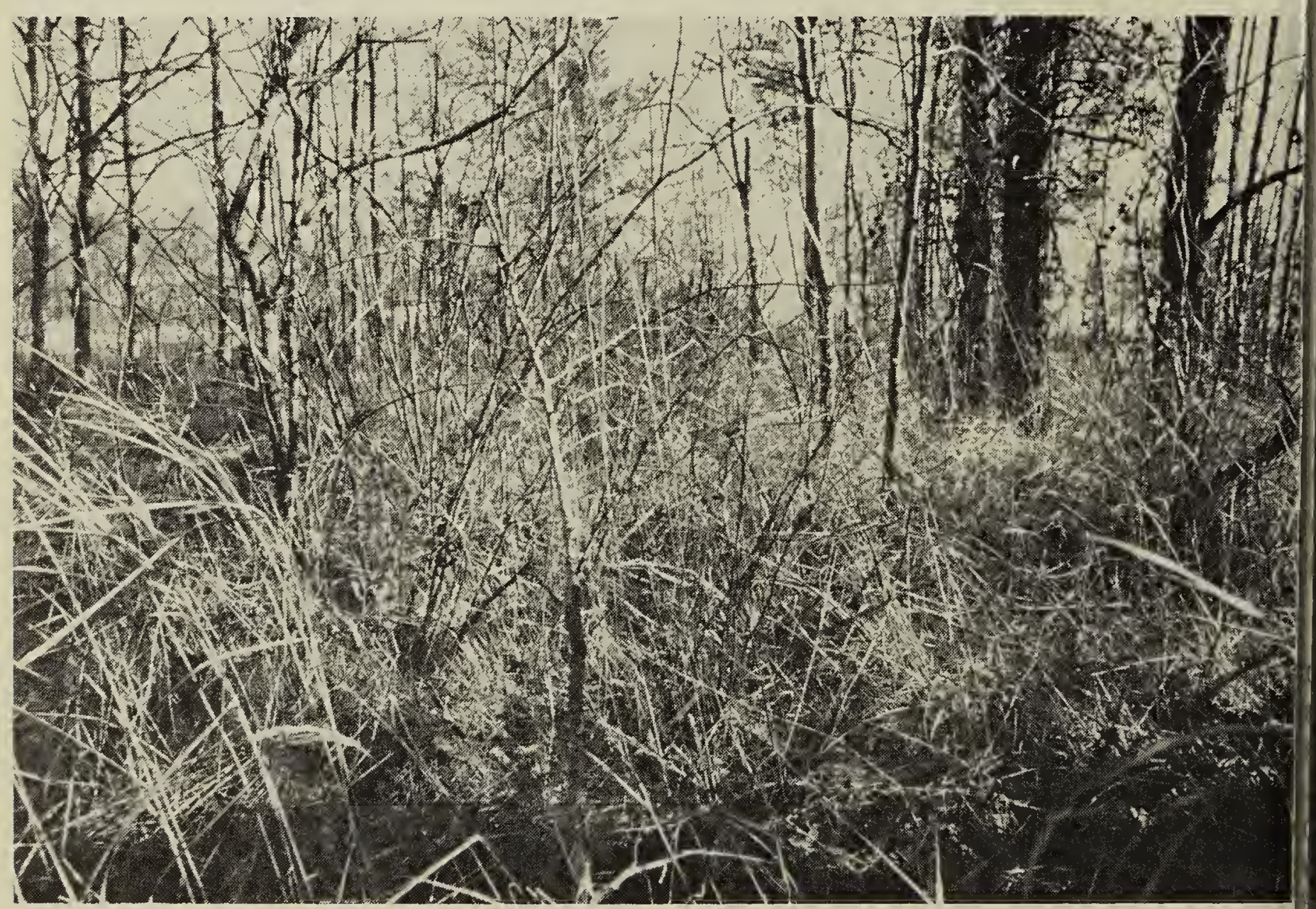

Site of first Manitoba woodcock nest. Note Jack Pine, mixed shrub and grass cover, and wal at lower left of photo.

Dennis $\mathrm{Fa}$ 
I was surprised to find that the nest was within 60 feet of the Monkman house in a most unlikely looking habitat. The nest was in a fairly open spot surrounded by Red-osier Dogwood, young aspens, and close to some Jack Pines. A small pool of water was within a foot or so of the nest. The eggs hatched about 25 May; three chicks survived and were led away by the female. One chick apparently drowned in an adjacent shallow pool and was obtained from Gary Monkman for the collections of the Manitoba Museum of Man and Nature (MMMN).

A second nest with four eggs was found by Michael Monkman on 2 May 1981, about 50 feet from the first site. Once again I was surprised to see how open the nest site was; apart from a few shrubs and a nearby Jack Pine there was little cover. The eggs hatched on 5 May, but only two chicks survived. The remaining two, which appeared weak, were apparently abandoned and shortly died (specimens in MMMN).

Further breeding information is available. On 1 June 1978, about 1530 1, Doreen and Des Whellams found an gdult woodcock with a chick crossing TH 44 near Westhawk Lake, about 1 nile east of Hanson's Creek. The adult lushed off the pavement in front of their far, leaving the chick crouching in the niddle of the road. The female bird folowed Des along the road when he pickd up the chick and carried it back to he car to show to his wife. The chick, which was well formed according to Whellmans, was presumably several fays old. When released it scurried off fter its parent.

Peter Taylor and Reto Zach disovered a half-grown young at their feet fter an adult flushed in front of them nd performed distraction display on 9 une 1978. This was on the edge of a leared area adjacent to mature aspen ith heavy undergrowth at Pinawa. larvey Lane and Peter Taylor flushed ree birds from this same spot on 14
June 1980. They presumed it was a family group.

While searching for a woodcock nest, Eugene $F$. Bossenmaier accidentally stepped on a flightless chick. This was on 23 June 1979, 2.5 miles south of Lewis (a hamlet on PTH 15; Sec. 1911-10E), about 45 miles east of Winnipeg. Gene noted that the primaries were $20 \mathrm{~mm}$ out of the sheath, again suggesting a bird several days old. This is in an area with a fairly large number of breeding birds. (Specimen is in MMMN).

A family group of woodcock was found by Raymond Tuokko at Pinawa Bay, north of Lac du Bonnet, 1 July 1979. An adult, presumably a female, was found with at least two fledglings. The young birds were seen at close hand on the ground but they were able to fly. This was in a mixed-wood cover. close to the Tuokko family residence.

Ken $H$. Doan reported finding a female with two chicks 4 miles west of Balmoral, some 18 miles north of Winnipeg. This was in a wet, mature aspen grove, 4 July 1979. The hen flushed and the chicks crouched, motionless.

Craig Maxwell reported a female with five chicks almost full grown, about July in 1979, at Manigotogan, 80 miles northeast of Winnipeg. The female came out and stood nearby, then led the chicks across the road. This extends the known breeding range for this species to the north.

Finally, another family group was observed by lan Ward and several other people on 24 May 1980, near Vivian just 35 miles east of Winnipeg on PTH 15 , about 1 mile west of the junction with $P R$ 302. The four young birds, which were almost full grown, followed both parents, slowly walking off the shoulder of the road and into cover. This is a breeding site which has been known for several years, but without previous observation of young.

Additional sightings shown in Table 1 
(n)

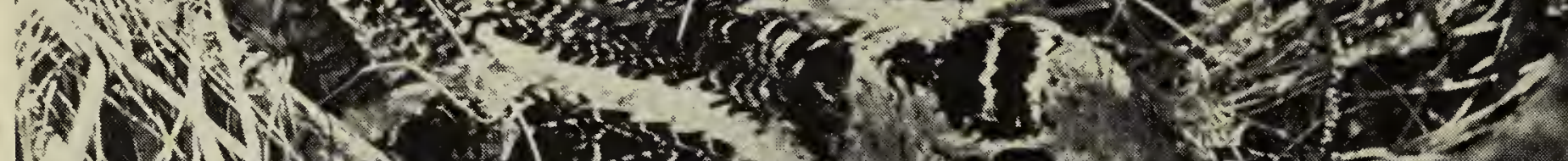

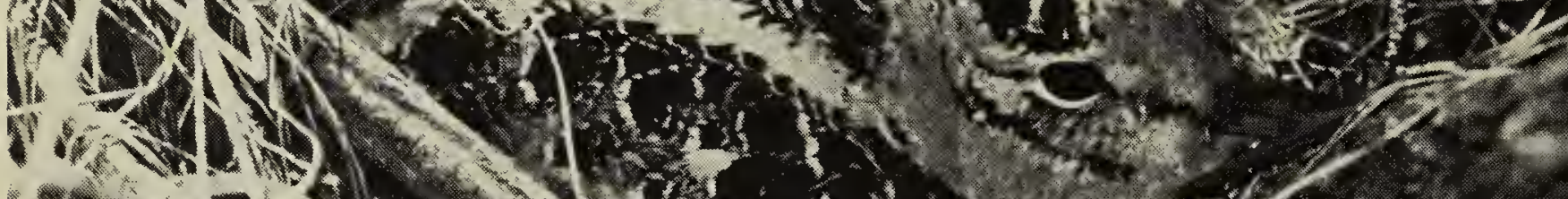

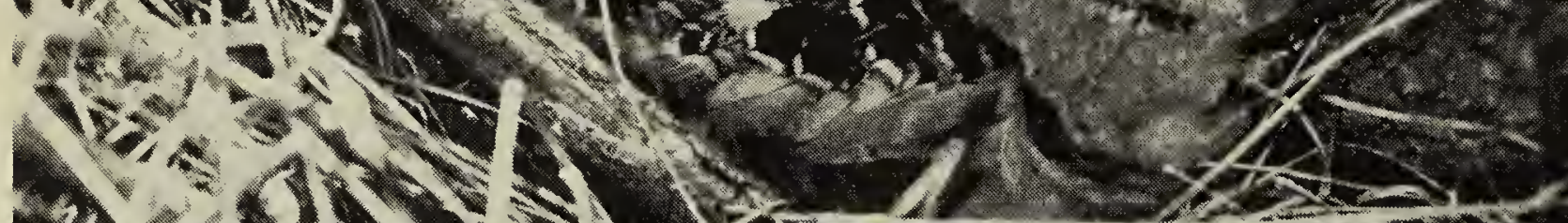
- Stls. (1) American Woodcock on nest, 21 May 1979, Richer, Manitoba. Dennis Fas

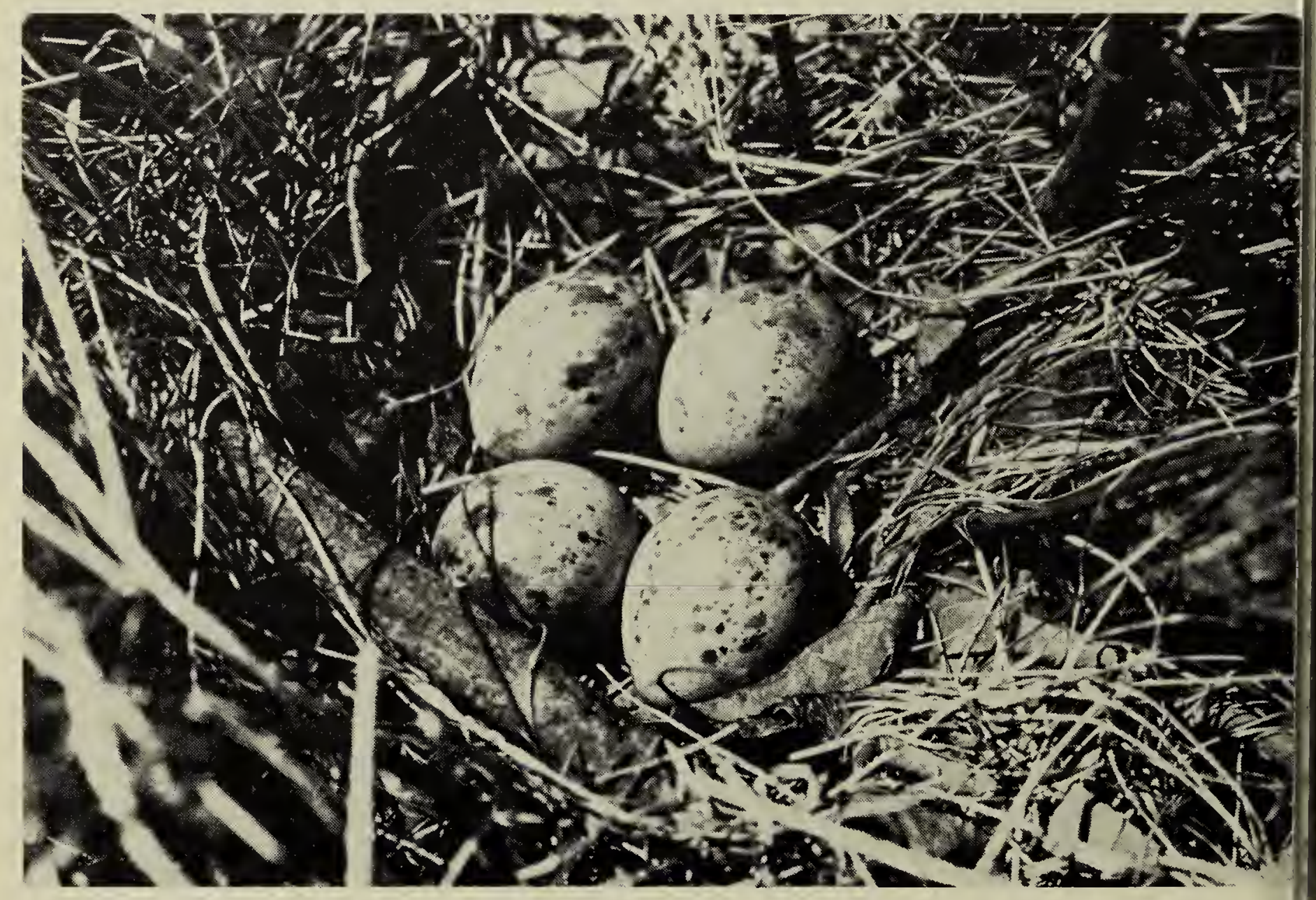

Full clutch of woodcock eggs, Richer, Manitoba.

Dennis Fas 
largely support previous observations, but the 1980 records from Riding Mountain National Park of an apparently single bird last seen 2 May are of special interest; only one previous record is known for that area (28 September 1933). The Ashern record, 90 miles northwest of Winnipeg (2 August 1978) further supports the assumption that woodcock occur in the Interlake region. Note that the 17 March 1981 record is apparently the earliest for the province; Tuokko's 28 October 1979 record is apparently the latest.

\section{Table 1. ADDITIONAL RECENT RECORDS OF WOODCOCK IN MANITOBA.*}

\begin{tabular}{|c|c|c|c|}
\hline Vear & Date & Place & Observer(s) \\
\hline 1976 & October & $\begin{array}{l}\text { Whiteshell P.P., near Dorothy \& Eleanor } \\
\text { Lakes (24!) }\end{array}$ & R. D. Sopuck \\
\hline & October & Elma & D. \& C. Elliott \\
\hline & June & Whiteshell P.P., Falcon L. village & E. Schindler \\
\hline 77 & July & Whiteshell P.P., PTH 44 \& Star Lake turnoff & D. Fitzjohn \\
\hline 77 & 3 September & Whiteshell P.P., Camp Lake, west shore & D. \& C. Elliott \\
\hline & 12 October & Whiteshell P.P., Betula Lake & M. Gillespie \\
\hline 78 & 25 April & Whiteshell P.P., jct. PTH 44 \& PR 307 & D. Fitzjohn \\
\hline 978 & 7 June & Whiteshell P.P., S of PR 301 & E. Schindler \\
\hline 978 & July & Whiteshell P.P., Falcon L. village & E. Schindler \\
\hline 978 & 3 July & Gelkirk, N on River Road & J. McDonald \\
\hline 978 & 19 July & Winnipeg, Transcona & R. Larche \\
\hline 978 & 2 August & Ashern, $3 \mathrm{mi}$ E on PR 325 & L. Colpitts, et al. \\
\hline 978 & 22 August & Milner Ridge & J. Ticknor \\
\hline 978 & 26 August & Winnipeg, near Assiniboine Forest & W. H. Koonz, et al. \\
\hline 978 & 20 September & Wampum, $0.75 \mathrm{mi} \mathrm{W}$ & P. Krahn \\
\hline 978 & "Fall" & Bissett, 5 mi W (rep. by American hunters) & C. Maxwell \\
\hline 979 & "early" May & Winnipeg, Assiniboine Forest (2) & R. W. Nero \\
\hline 979 & 15 June & Jct. PTH 44 \& PTH 11 & L. Higgens \\
\hline 79 & 22 June & Elma, $0.5 \mathrm{mi} \mathrm{N}$ & L. Higgens \\
\hline y & 19 October & Richer area, Project 13, 1 mi S PTH 1 & M. Comeau \\
\hline 979 & 28 October & Lac du Bonnet, Pinawa Bay & R. Tuokko \\
\hline 979 & October & Manigotogan, $4 \mathrm{mi} \mathrm{N}$ & C. Maxwell \\
\hline 980 & 10 April & Headingley, S of Assiniboine R. & $\begin{array}{l}\text { P. Laufersweiler, } \\
\text { J. Flannigan }\end{array}$ \\
\hline 80 & 23 April & Riding Mountain Natl. Park, 3.5 mi E Wasagaming & C. Davar \\
\hline 30 & 26 April & Riding Mountain Natl. Park & W. J. Walley \\
\hline 80 & 2 May & Riding Mountain Natl. Park (last seen) & C. Davar \\
\hline 981 & 17 March & Winnipeg, 326 Winchester & Mr. \& Mrs. J. Jenkins \\
\hline 981 & 28 March & Winnipeg, Charleswood Road, S of Wilkes & P. Caldwell \\
\hline 981 & 28 March & Prawda, 2 mi N & $\begin{array}{l}\text { H. W. R. Copland } \\
\text { R. W. Nero }\end{array}$ \\
\hline & $28 \mathrm{March}$ & $\begin{array}{l}\text { Lac du Bonnet area; four birds seen on PR } 214 \text {, } \\
\text { a mile west of PTH } 11\end{array}$ & P. Taylor \\
\hline & 29 March & Glen Road, E Braintree & $\begin{array}{l}\text { H. W. R. Copland, } \\
\text { R. W. Nero }\end{array}$ \\
\hline 8 & $\begin{array}{l}3 \text { April } \\
5 \text { Anril }\end{array}$ & Stonewall, $5 \mathrm{mi} \mathrm{W}$ & $\begin{array}{l}\text { D. Soprovitch } \\
\text { R. R. Taylor }\end{array}$ \\
\hline
\end{tabular}

Single sightings unless otherwise noted; breeding records not included. 